\title{
JUDICIAL VALIDITY OF DISHONOR OF CHEQUE
}

\author{
Renu Chaudhary \\ Research scholar, Himalayan Garhwal University \\ DOI: 10.46609/IJSSER.2020.v05i08.020 URL: https://doi.org/10.46609/IJSSER.2020.v05i08.020
}

\section{Introduction}

Banking system is the lifeline of a country's economy. India is one of the fast developing countries in terms of economic growth and invaluable human resources. The healthy economy of a country depends largely upon an effective banking system that assures trust and credibility in trade and commerce.

\section{Purpose}

The purpose of the Act was to present an orderly and authoritative statement of the leading rules of law relating to the negotiable instruments. The Act intends to legalize the system under which claims upon mercantile instruments could be equated with ordinary goods passing from hand to hand.

In the present economic scenario encouraging the culture of use of cheques and enhancing the credibility of the instruments has become prime necessity in modern commercial transactions and dealing in money.

With this view, the N.I. Act, 1881 was amended in 1988 by the Banking Public Financial Institutions and Negotiable Instruments Laws (Amendment) Act, 1988. Broadly speaking the main objects and reason of amending provisions are:

Firstly, to encourage the culture of use of cheques, and Secondly, to enhance the credibility of the cheque in commercial transactions.

In N.E.P.C. Mecon Ltd. v. Magma Leasing Ltd., the Supreme Court observed that the object of bringing Section 138 on statute appears to to inculcate faith in the efficacy of banking operations and credibility in transactions in business the efficacy of banking operations and credibility in transactions in business on negotiable instruments and to promote the efficacy of banking operations and to ensure credibility in transacting business through cheques. 


\section{International Journal of Social Science and Economic Research}

ISSN: $2455-8834$

Volume:05, Issue:08 "August 2020"

Further, the Supreme Court observed that Section 138 of the Act has created contractual branch as an offence and the legislative purposes is to promote efficacy of banking and of enduring that in commercial or contractual transactions cheques are not dishonored and credibility in transacting business through cheques is maintained.

The object of new chapter appears to be to inculcate faith in the efficacy of banking operations and credibility in transacting business of negotiable instruments. Besides the availability of civil remedy against the drawer for the recovery of money, Section 138 intends to prevent dishonesty on the part of the drawer of negotiable instruments to draw a cheque without sufficient funds in the account maintained by him in a bank and induces the payee or holder in due course to act upon it.

\section{Constitutional Validity of Section 138}

The validity of section of 138 of the Negotiable Instruments was challenged before the Maharashtra High Court5 in Narayanadas Bhagwandas Partani v. Union of India, ${ }^{1}$ contending therein that the provisions of this section are violative of Article of 14 of the Constitution of India. The Court examined the matter in detail taking into consideration the facts of the case and various articles of the Indian Constitution and observed that the importance of banking section in the developing economy could not be under-rated. Further, it is in the larger public interest that commercial transactions maintain the speed and tempo and that a swift sale or a prompt purpose, is not unduly impeded by suspicions always hovering round that part of promise to be performed in future. The issue of a cheque carries with it assumptions which could regulate the normal functioning of an honest citizen. At a period of time when multitudinous persons and institutions press into services, devices and facilities available under the Negotiable Instruments Act, it may be necessary to ensure that those who issue such vital documents, do not adopt a casual or careless attitude which could block the free flow of trade. It is in the light of the experience, which the State had, that the enactment has been attempted. Court is unable to detect any legal infirmity or constitutional incompetence.

Furthermore, no attempt has been made out as to show how Article 20 of the Constitution can be attracted to such a situation. The statute, therefore, cannot be struck down, merely because the petitioners desire to see its collapse. Entry Nos. 45 and 46 respectively, refer to Banking, Bills of Exchange, Promissory Notes and other instruments. The impugned provisions, would come well

${ }^{1} 1993$ Mah し 1229. 


\section{International Journal of Social Science and Economic Research}

ISSN: $2455-8834$

Volume:05, Issue:08 "August 2020"

within the larger ambit of the entries. It is connected with negotiable instrument, which clearly come with the aforesaid entries dealing with legislative power.

Court is unable to see any provision in arbitrariness or infraction of Article 14 of the Constitution. Those who deal in negotiable instruments are not to resort to sharp practices. A time consuming civil litigation may not give immediate or adequate remedy to the victims of an illegal act or a dishonest move. The Parliament could then make a provision with sufficient teeth, as to strongly deal with the ruffians in the trading area, or the unscrupulous elements who play foul with negotiable instrument.

The offence is not the drawing of the cheque. The offence takes places when a cheque is returned unpaid on the twin grounds as contained in Section 138 of the Negotiable Instruments Act, 1881.

Thus, there is a retrospective operation. The Madras High Court has held that laws made justly and for the benefit of individuals and for the community as a whole may relate to time antecedent to their commencement. The conclusion would be that such prosecution is not hit by Article 20 (1) of the Constitution which provides that "no person shall be convicted of any offence except for violation of the law in force at the time of the commission of act charged as an offence, nor be subjected to a penalty greater than that which might have been inflicted under the law in force at the time of the commission of the offence.

\section{Special Conclusion}

In view of the guidelines laid down by the Apex Court with regard to compounding of the offence 40 after appearance of the accused in the court and before starting of trial, after making the accused understand about the consequences of the trial and punishment provided in the offence, should be given one opportunity to make payment of the cheque amount with reasonable interest and costs as fixed by the court and if the same is paid within the time granted by the court, then the complaint should not be allowed to proceed further. But if this concession is not availed by the accused and ultimately he is found guilty then strict and harsh punishment can be awarded. This mandatory concession at the initial stage would also reduce the litigation and shall be in the interest of both the parties to maintain harmonies relations for future also.

It has also been suggested that banks must adopt a differential pricing pattern for transactions conducted in a paper-based manner, in order to sensitize customers to use electronic modes of fund transfer. It has also recommended that banks levy a charge for all paper-based cheques. As of now, banks themselves bear the service charges for MICR processing of cheques. For this, banks will require to educate customers on the need to migrate to electronic processing and make electronic fund transfers cheaper than paper modes ${ }^{\mathrm{i}}$. 
Electronic payments would spell major gains. For banks trying to lower branch-banking costs, by encouraging customers to avail of internet banking; for trade and commerce, for whom instantaneous funds transfer means a huge saving in costs; for tax authorities, who will get a handle on transactions that otherwise are off their radar, and for ordinary citizens who will get speedier service. Replacing cheques with electronic payments will also be environment friendly.

i $h$ ttp://timesofindia.indiatimes.com/business/india-business/Validity-of-cheques-drafts-cut-to3-months/articleshow/10626994.cms, accessed on April 21, 2016. 